Western University

Scholarship@Western

Law Publications

Law School

2008

Battleground between New and Old Orders: Control Conflicts between Copyright and Personal Data Protection

Margaret Ann Wilkinson

WesternUniversity,mawilk@uwo.ca

Follow this and additional works at: https://ir.lib.uwo.ca/lawpub

Part of the Intellectual Property Law Commons

Citation of this paper:

Wilkinson, Margaret Ann, "Battleground between New and Old Orders: Control Conflicts between Copyright and Personal Data Protection" (2008). Law Publications. 44.

https://ir.lib.uwo.ca/lawpub/44 


\title{
10. Battleground between new and old orders: control conflicts between copyright and personal data protection
}

\author{
Margaret Ann Wilkinson ${ }^{1}$
}

\section{INTRODUCTION}

In 2005, the Federal Court of Appeal had the opportunity to consider the relationship between notions of privacy and conceptions of intellectual property in BMG Canada Inc. v. John Doe. ${ }^{2}$ Justice Sexton, for the court, wrote:

Modern technology...must not be allowed to obliterate those personal property rights which society has deemed important. Although privacy concerns must also be considered, it seems to me that they must yield to public concerns for the protection of intellectual property rights in situations where infringement threatens to erode those rights. ${ }^{3}$

In the context of exploring the issues that were before the Court of Appeal in that case, this chapter will explore three themes emanating from this paragraph. First, Justice Sexton equates intellectual property with property rights - an increasingly prevalent rhetoric in an age when property rights holders who have come into the ascendancy during the industrial age are challenged by the recent migration of wealth from manufacturing to the internet, from the industrial age to the information age. Second, Justice Sexton juxtaposes

1 The author has been supported in this work through funding received from the Social Sciences and Humanities Research Council of Canada. Law student Vanessa Bacher provided timely research assistance. The author would also like to thank the reviewer of an earlier draft of this paper for most thoughtful suggestions.

2 BMG Canada Inc. v. John Doe, [2005] 4 F.C.R. 81, (2005), 39 C.P.R. (4th) 97, Sexton J.A. [BMG FCA cited to F.C.R.], aff'g BMG Canada Inc. v. John Doe, [2004] 3 F.C.R. 241, (2004), 32 C.P.R. (4th) 64, von Finckenstein J. [BMG FC cited to F.C.R.].

Ibid. at para. 41 . 
privacy and intellectual property - and gives priority to intellectual property. Third, Justice Sexton cites 'public concerns for the protection of intellectual property rights' and this begs an examination of notions of the public interest.

It is perhaps not unexpected that a dispute such as this would arise from the present highly charged environment of music. Music is an area where industrial players have, in the past, particularly benefited from past extensions of copyright law. In the immediate past, the music industry is also one that has enjoyed considerable success, particularly in the US, in influencing legislators to further amend copyright legislation to perpetuate and shore up the industrial model. ${ }^{4}$ In Canada, the music industry has a long history of collective representation, ${ }^{5}$ recently strengthened by further legislative recognition of collectives for all rights holders. ${ }^{6}$ In this litigation, the music companies themselves were the plaintiffs: BMG is just the first named plaintiff - the other plaintiffs are fellow members of the Canadian Recording Industry Association (CRIA). ${ }^{7}$

4 See Pamela Samuelson, 'Digital Rights Management \{and, or, vs. \} the Law' (April 2003) 46:4 Communications of the ACM 41. Samuelson writes that the Hollywood industry has long influenced copyright policy in the United States, using such measures as the Audio Home Recording Act (AHRA) of 1992, which required the installation of copy management chips in digital audiotape technologies and videocassettes, and today through their ownership of key patents for DVD players, thus controlling the anti-copying technology built into them. They also have a mandate to increase the prevalence of Digital Rights Management technology in their products. For further illustration of the recording industry's influence, see Amy Harmon 'Music Industry in Global Fight on Web Copies' The New York Times (7 October 2002), online: New York Times <http://www.nytimes.com/2002/10/07/technology/07SWAP.html> (on legal action taken over file-sharing programs in the US). See also Metro-Goldwyn-Mayer Studios Inc. et al. v. Grokster, Ltd. et al., 545 U.S. 913 (2005) at para 1, where the Supreme Court ruled against file-sharing software providers, concluding: 'one who distributes a device with the object of promoting its use to infringe copyright, as shown by clear expression or other affirmative steps taken to foster infringement, is liable for the resulting acts of infringement by third parties.'

5 Dating back to 1925 when the Canadian Performing Rights Society, an offshoot of the British Performing Rights Society, was established. In 1940, BMI Canada emerged.

6 In 1988 the Canadian Copyright Act, R.S.C. 1985, c. C-42 [Copyright Act] was amended to except rightholders' collectives from the rigours of the Competition Act, R.S.C. 1985, c. C-34. This encouraged the formation of many rightsholders' collectives. See Mario Bouchard, 'Collective Management in Commonwealth Jurisdictions: Comparing Canada and Australia' in Daniel Gervais, ed., Collective Management of Copyright and Related Rights (The Netherlands: Kluwer Law International, 2006) 283 at 285.

7 EMI Music Canada, a Division of EMI Group Canada Inc., Sony Music Entertainment (Canada) Inc., Universal Music Canada Inc., Warner Music Canada Ltd., BMG Music, Arista Records Inc., Zomba Recording Corporation, EMI Music Sweden AB, Capitol Records, Inc., Chrysalis Records Limited, Virgin Records 
CRIA is not a copyright collective: ${ }^{8}$ rather it is 'a non-profit trade organization that was founded in 1964 to represent the interests of Canadian companies that create, manufacture and market sound recordings', 9 although it maintains 'a Division to enforce the various rights in copyright of its members and to investigate and initiate legal action in response to piracy'. ${ }^{10}$ Further, '[i]n association with its international affiliates, CRIA's Anti-Piracy Division monitors internet sites in Canada for unauthorized use of sound recordings' ${ }^{11}$ Unlike the practice of many copyright collective associations, ${ }^{12}$ CRIA does not take

Limited, Sony Music Entertainment Inc., Sony Music Entertainment (UK) Inc., UMG Recordings, Inc., Mercury Records Limited, and WEA International Inc.

8 In the 1988 reforms, copyright holder collectives were exempted from the rigours of the Competition Act. See Copyright Act, supra note 6, s. 70.5. For an interesting discussing of the situation of users' collectives, as opposed to copyright holders' collectives, see Catherine A. Maskell, 'Consortia: Anti-competitive or in the public good?' (2008) 26:2 Library Hi-Tech 164. The definition of 'collective society' was added to the Canadian Copyright Act in 1997 by S.C. 1997, c.24, s. 1(5):

a society, association or corporation that carries on the business of collective administration of copyright or of the remuneration right conferred by section 19 [re: rights in sound recordings] or 81 [re: private copying of sound recordings] for the benefit of those who, by assignment, grant of license, appointment of it as their agent or otherwise, authorize it to act on their behalf in relation to that collective administration, and

(a) operates a licensing scheme, applicable in relation to a repertoire of works...or more than one author ... pursuant to which the society, association or corporation sets out classes of users that it agrees to authorize under this Act, and the royalties and terms and conditions on which it agrees to authorize those classes of users, or (b) carries on the business of collecting and distributing royalties, or levies payable pursuant to this Act.

CRIA is not included in the compendium of Canadian collective societies available on the website of the Copyright Board of Canada, Copyright Board of Canada, 'Copyright Collective Societies', online: <http://www.cb-cda.gc.ca/societies/index-e.html>.

9 Canadian Recording Industry Association, 'About CRIA', online: $<$ http://www.cria.ca/about.php>.

10 See \#1 in CRIA's list of anti-piracy efforts: CRIA, 'What we do?', online: $<\mathrm{http} / / /$ www.cria.ca/whatwedo.php $>$. Also see Jonathan Fowlie 'Music police trumpet piracy bust' The Globe \& Mail (9 July 2004) A1, A10. On Thursday 8 July 2004, the RCMP announced that, tipped off by the CRIA, they had confiscated an enormous cache of over 1,100 DVDs and 1,500 VHS tapes, 'the most ever taken at one time,' bootlegged from music concerts and shows. An individual from Hamilton was charged with five counts of copyright infringement. On the following Monday, 12 July 2004, the members of CRIA filed their appeal from the decision of Justice von Finckenstein.

11 See \#6 in CRIA's list of anti-piracy efforts, ibid..

12 The Society of Composers, Authors and Music Publishers of Canada 
an assignment from its members of the copyright interest it represents and thus is not directly a litigant in proceedings such as this case.

CRIA's members, then, launched this lawsuit against 'John Doe, Jane Doe and all those persons who are infringing copyright in the plaintiffs' sound recordings'. In particular, ${ }^{13}$ the plaintiffs alleged that the defendants were infringing their rights:

- To reproduce sound recordings in a material form ${ }^{14}$

- To authorize the reproduction of sound recordings in a material form ${ }^{15}$

The infringements alleged were both primary infringement ${ }^{16}$ and, by distributing (to such an extent as to affect prejudicially the owner of copyright) unauthorized reproductions and possessing the unauthorized reproductions in order to effect the distribution, secondary infringement. ${ }^{17}$

The challenge facing the plaintiffs as they commenced this litigation in the Federal Court was inherent in the technology of the internet: although they knew that works in which they held copyright interests were circulating widely on the internet without their permission, they did not know the identities of those whom they alleged were infringing their rights to reproduce or authorize reproduction. They alleged that activity at 29 internet service provider addresses was evidence of infringement. ${ }^{18}$ However, all 29 addresses could be identified by the plaintiffs only in terms of the online pseudonyms that the internet users at those addresses used. Thus the plaintiffs brought the interlocutory motion, which created the context for the judgments on which this article focuses. The motion was brought before Justice von Finckenstein under Federal Court Rules $233^{19}$ and $238,{ }^{20}$ against five Canadian internet

(SOCAN), for example, takes an assignment from its members of performing rights in music, including rights to communicate music by telecommunication, and therefore, in litigation proceedings, SOCAN is itself a party.

13 BMG FC, supra note 2 at para. 22.

14 Copyright Act, supra note 6, s. 18(1)(b).

15 Ibid. at s. $18(1)$.

16 Ibid. at s. 27(1).

17 Ibid. at s. 27 (2)(b), (d). This is a relatively new section of the Act, added in 1997.

$18 B M G F C$, supra note 2 at para. 3. The plaintiffs submitted that over 1000 songs had been downloaded by users at each of these 29 internet addresses.

19 Federal Court Rules, S.O.R./98-106, r. 233 (1). On motion, the Court may order the production of any document that is in the possession of a person who is not a party to the action, if the document is relevant and its production could be compelled at trial.

20 Ibid. at $\mathrm{r} .238$ (1). A party to an action may bring a motion for leave to examine for discovery any person not a party to the action, other than an expert witness for a party, who might have information on an issue in the action. 
service providers ${ }^{21}$ to compel these ISPs to disclose the names of their customers who used the ISP addresses alleged to be relevant to the infringement lawsuit. ${ }^{22}$ It is important to note that all parties to this motion agreed on two points:

[1.] ISP account holders have an expectation that their identity will be kept private and confidential. This expectation of privacy is based on both the terms of their account agreements with the ISPs and sections 3 and 5 of the Personal Information Protection and Electronic Documents Act (PIPEDA).

[2.] The exceptions contained in PIPEDA apply in this case and an ISP by virtue of s. 7(3)(c) of PIPEDA may disclose personal information without consent pursuant to a court order. ${ }^{23}$

In the first instance, Justice von Finckenstein decided that the test that he ought to apply, in deciding whether to grant the applicants' motion, ${ }^{24}$ had the following five parts: ${ }^{25}$

(a) the applicant must establish a prima facie case against the unknown alleged wrongdoer;

(b) the person from whom discovery is sought must be in some way involved in the matter under dispute, he must be more than an innocent bystander;

21 Shaw Communications Inc., Roger Cable Communications Inc., Bell Canada, Telus Inc., and Vidéotron Ltée.

$22 B M G F C$, supra note 2 at para. 6. Electronic Frontier Canada and the newly established Canadian Internet Policy and Public Interest Clinic of the Faculty of Law at the University of Ottawa (CIPPIC) were granted intervener status for the purpose of making arguments.

23 Ibid. at para. 9.

24 Ibid. at para. 15.

25 Ibid. at para. 13. See also Federal Court Rules, supra note 19, r. 238(3) set out in Annex A to the judgment:

The Court may, on a motion under subsection (1) [set out above], grant leave to examine a person and determine the time and manner of conducting the examination, if it is satisfied that

(a) the person may have information on an issue in the action;

(b) the party has been unable to obtain the information informally from the person or from another source by any other reasonable means;

(c) it would be unfair not to allow the party an opportunity to question the person before trial; and

(d) the questioning will not cause undue delay, inconvenience or expense to the person or to the other parties. 
(c) the person from whom discovery is sought must be the only practical source of information available to the applicants;

(d) the person from whom discovery is sought must be reasonably compensated for his expenses arising out of compliance with the discovery order in addition to his legal costs;

(e) the public interests in favour of disclosure must outweigh the legitimate privacy concerns.

Of these criteria, Justice von Finckenstein found that the applicant plaintiffs had satisfied (b), ${ }^{26}$ (d), ${ }^{27}$ but not (a), ${ }^{28}$ (c),${ }^{29}$ or (e).${ }^{30}$ Therefore, he denied the motion. ${ }^{31}$

The plaintiff applicants appealed the denial of their motion to the Federal Court of Appeal. Justice Sexton, as mentioned above, delivered the judgment for himself, Justice Noël and Chief Justice Richard. ${ }^{32}$ The Court of Appeal itself characterized the outcome of the appeal as one of 'divided success'33 however, the appeal was dismissed. ${ }^{34}$ The characterization of 'divided success' was made because this dismissal was 'without prejudice to the plaintiffs' right to commence a further application for disclosure of the identity of the "users" taking into account these reasons'. 35

The Court of Appeal upheld Justice von Finckenstein's view that Rule 233 of the Federal Court was not available to the plaintiffs on these facts. ${ }^{36}$ The Court of Appeal agreed that Justice von Finckenstein had used the appropriate five criteria to determine the outcome of the motion with respect to Rule 238. ${ }^{37}$ The Court of Appeal also agreed in the result with Justice von Finckenstein's finding that the plaintiffs had failed to establish a prima facie case against the unknown alleged wrongdoer. ${ }^{38}$ However, the Court of Appeal,

\footnotetext{
$26 \quad$ Ibid. at para. 30.

27 Ibid. at para. 35.

28 Ibid. at para. 43.

29 Ibid. at paras. $31,43$.

30 Ibid. at paras. $42-3$.

31 Ibid. at para. 47. In obiter in paras. 44-6, Justice von Finckenstein described the scope and terms of the order he would have given had the motion succeeded.

32 Only CIPPIC intervened in the case at this level.

33 BMG FCA, supra note 2 at para. 56.

34 Ibid. at para. 55.

35 Ibid. at paras. 55, 56. All parties had to bear their own costs of the appeal.

36 Ibid. at paras. 17-19.

37 Ibid. at para. 30, Sexton J. 'In my view, the plaintiffs could invoke either Rule 238 or equitable bills of discovery and, in either case, the legal principles relating to equitable bills of discovery would be applicable', this agreement was subject to a caveat concerning the first branch of the test, which will be set out just below.

38 Ibid. at para. 21.
} 
in agreeing that this motion should be denied, focussed on the deficiencies in the evidence presented in this proceeding, which was primarily hearsay: ${ }^{39}$ the Court of Appeal, on the other hand, confirmed that it is possible to bring a motion to compel identification of persons committing infringements of copyright under Rule 238. ${ }^{40}$ Moreover, the Court of Appeal disagreed with Justice von Finckenstein's statement of the first branch of the test, that, to succeed on such a motion, the plaintiffs had to provide evidence of a prima facie case, ${ }^{41}$ and stated that the correct test was whether the plaintiffs had a bona fide claim. ${ }^{42}$ It would have been sufficient, therefore, in the eyes of the Court of Appeal, if the plaintiffs had been able to establish, on this branch of the five part test, that 'they really do intend to bring an action for infringement of copyright based upon the information they obtain, and that there is no other improper purpose for seeking the identity of these persons' ${ }^{43}$

The Court of Appeal specifically agreed with Justice von Finckenstein's 'characterization of the 5th criteria - that is - the public interest in favour of disclosure must outweigh the legitimate privacy concerns of the person sought to be identified if a disclosure order is made'. ${ }^{44}$ Justice von Finckenstein had written that:

This motion is not a novel proceeding. In the past, third parties have been compelled to disclose documents identifying the name and address of a defendant previously identified solely by an Internet Protocol address. In no case have privacy or other concerns weighing against disclosure outweighed the interest in obtaining documents and information necessary to identify the defendants [authorities omitted].

In this case, the plaintiffs have a legitimate copyright in their works and are entitled to protect it against infringement... 45

In the same vein, Justice Sexton, for the Court of Appeal, held 'in my view, in cases where plaintiffs show that they have a bona fide claim that unknown persons are infringing their copyright, they have a right to have the identity revealed for the purpose of bringing action'. ${ }^{46}$ Justice von Finckenstein in the first instance found, that despite the plaintiffs' legitimate interests in protecting

\footnotetext{
39 Ibid..

$40 \quad$ Ibid. at para. 25.

41 BMG FC, supra note 2 at paras. 13, 43. See the language of Von Finckenstein J. referring to 'a prima facie case.'

42 BMG FCA, supra note 2 at para. 32.

43 Ibid. at paras. 34, 54. FCA judgment specifically did not accept Justice von Finckenstein's statements of copyright law and findings relating to the merits of the claim for infringement.
$44 \quad$ Ibid. at para. 36.
45 BMG FC, supra note 2 at paras. 41-2.
46 BMG FCA, supra note 2 at para. 42. 
themselves against infringers, they had left too long a period of time between the alleged infringements and their quest for the infringers' identities and that this gap raised 'the serious possibility of an innocent account holder being identified' ${ }^{47}$ Justice Sexton, for the Court of Appeal, was also concerned about delay - and for the same reasons:

it is possible that the privacy rights of innocent persons would be infringed and legal proceedings against such persons would be without justification. Thus the greatest care should be taken to avoid delay between the investigation and the request for information. Failure to take such care might well justify a court in refusing to make a disclosure order. ${ }^{48}$

Justice Sexton went on to say:

In any event, if a disclosure order is granted, specific directions should be given as to the type of information disclosed and the manner in which it can be used. In addition, it must be said that where there exists evidence of copyright infringement, privacy concerns may be met if the court orders that the user only be identified by initials, or makes a confidentiality order. ${ }^{49}$

Thus, at the end of the day, much of what the Court of Appeal in BMG Canada Inc. v. John Doe says about privacy and personal data protection is obiter - just as the decision of the original motions judge, Justice von Finckenstein, did not depend upon his findings about the relationship between the plaintiffs' intellectual property rights and the privacy or personal data protection interests of the owners of the targeted internet accounts. Nonetheless, and notwithstanding the fact that there are other decisions which have involved disclosure of identities in litigation involving the internet, both Justice von Finckenstein and the Federal Court of Appeal express in this case attitudes toward the relationship between privacy and personal data protection interests and intellectual property interests that bear close scrutiny.

This scrutiny is particularly warranted in light of the comments made by Justice LeBel, dissenting in part, in Society of Composers, Authors and Music Publishers of Canada v. Canadian Association of Internet Providers. ${ }^{50}$ This decision, also involving music in the internet environment, was released on 30 June $2004,{ }^{51}$ between the time that Justice von Finckenstein gave his judgment

\footnotetext{
$47 \quad B M G F C$, supra note 2 at para. 42.

48 BMG FCA, supra note 2 at para. 43.

49 Ibid. at para. 45.

50 Society of Composers, Authors and Music Publishers of Canada v. Canadian Assn. of Internet Providers, [2004] 2 S.C.R. 427, Binnie J. [Tariff 22].

51 The majority decision was written by Justice Binnie, for himself and Justices Iacobucci, Major, Bastarache, Arbour, Deschamps, Fish and Chief Justice McLachlin.
} 
in BMG Canada Inc. v. John Doe, on 31 March 2004, and the judgment of the Court of Appeal on 19 May 2005, and was not referred to by the Court of Appeal. In the Tariff 22 decision, Justice LeBel writes

...In general, once the content provider has posted content on a host server, it is available to the public. Owners of copyright works and their collective societies can easily monitor such public content by trawling the publicly accessible servers with specially designed software. Privacy concerns are diminished because it is the content provider who has made the information public by posting it on the server. Although privacy concerns are attenuated, they are not eliminated [by the approach he was proposing in the Tariff 22 case]. It is now common for Internet site operators to collect personal data from end users when users visit their Web site...But that is a question for another day. ${ }^{52}$

That 'other day', forecast by Justice LeBel, was indeed before the courts in $B M G$ v. John Doe, but Justice LeBel gave an indication of his perspective in such a case when, as the only member of the Supreme Court to raise privacy issues in Tariff 22, he warned:

By contrast, the real and substantial connection test [the test adopted by the majority in the Tariff 22 decision], insofar as it looks at the retrieval practices of end users, encourages the monitoring of an individual's surfing and downloading activities. Such habits tend to reveal core biographical information about a person. Privacy interests of individuals will be directly implicated where owners of copyrighted works or their collective societies attempt to retrieve data from Internet Service Providers about an end user's downloading of copyrighted works. We should therefore be wary of adopting a test that may encourage such monitoring. ${ }^{53}$

The industry and environment concerned are identical in the two cases. The Supreme Court, in Tariff 22, noted ' $[\mathrm{t}]$ he issue of the proper balance in matters of copyright plays out against the much larger conundrum of trying to apply national laws to a fast-evolving technology that in essence respects no national boundaries'. 54 The Tariff 22 litigation concerned 'the difficult issue of who should compensate musical composers and artists for their Canadian copyright in music downloaded in Canada from a foreign country via the Internet' ${ }^{55}$ In $B M G$ v. John Doe, participants in the music industry were also trying to enforce their rights in the internet environment, seeking compensation for music. As in the interim motion proceedings involved in BMG v. John Doe, the

\footnotetext{
52 Tariff 22, supra note 50 at para. 154, LeBel J., dissenting.

53 Ibid. at paras. 153-155, LeBel J., dissenting.

54 Ibid. at para. 41.

55 Ibid. at para. 1.
} 
targets in the Tariff 22 litigation were the internet service providers (ISPs). ${ }^{56}$ In the Tariff 22 situation, the root of the litigation lay in the factual reality that '[a]t this point the prospect of seeking to collect royalties from foreign infringers is not an attractive prospect for SOCAN' ${ }^{57}$ - and therefore SOCAN sought (unsuccessfully, in the end) to obtain revenue by imposing tariff obligations on Canadian ISPs. The root of the BMG v. John Doe litigation lies in the fact that 'Canada's music producers and recording industry are very concerned about infringement of copyright in their musical works through the use of Internet file sharing' and they did not have access to the identities of the alleged infringers; but the ISPs did. ${ }^{58}$

In finding that Canadian ISPs could not be made subject to the tariff at issue before them in the Tariff 22 case, the Supreme Court observed:

The knowledge that someone might be using neutral technology to violate copyright...is not necessarily sufficient to constitute authorization...An overly quick inference of 'authorization' would put the Internet Service Provider in the difficult position of judging whether the copyright objection is well founded, and to choose between contesting a copyright action or potentially breaching its contract with the content provider. ${ }^{59}$

The Court went on to observe: 60

Parliament made a policy distinction between those who abuse the Internet to obtain 'cheap music' and those who are part of the infrastructure of the Internet itself. It is clear that Parliament did not want copyright disputes between creators and users to be visited on the heads of Internet intermediaries, whose continued expansion and development is considered vital to national economic growth. ${ }^{61}$

Moreoever, Justice LeBel, concurring with the majority on this part of the judgment, but alone in specifically raising privacy concerns, stated:

56 In the Tariff 22 context, the ISPs were the targets of the action itself: the litigation before the Supreme Court of Canada was an interim proceeding taken to determine whether the Copyright Board of Canada had jurisdiction to impose a tariff for the benefit of SOCAN on Canadian ISPs.

57 Tariff 22, supra note 50 at para. 81.

58 BMG FCA, supra note 2 at para 2.

59 Tariff 22, supra note 50 at para. 127 (Binnie, J. for the majority of the Court, LeBel, J., concurring in these areas).

60 In the context of s. 2.4(1)(b) of the Copyright Act which was at issue in the case.

61 Tariff 22, supra note 50 at para. 131 (Binnie, J. for the majority of the Court, LeBel, J., concurring in these areas). 
Insofar as is possible, this Court should adopt an interpretation of [the section at issue] that respects end users' privacy interests, and should eschew an interpretation that would encourage the monitoring or collection of personal data gleaned from Internet-related activity within the home...

The attitudes of both the majority ${ }^{62}$ and minority in Tariff 22 may be contrasted with the attitudes of both Justice von Finckenstein and the Federal Court of Appeal in BMG v. John Doe, expressed most forcefully in the judgment of Justice Sexton: 'in my view, in cases where plaintiffs show that they have a bona fide claim that unknown persons are infringing their copyright, they have a right to have the identity revealed [by ISPs] for the purpose of bringing action [emphasis here added]' ${ }^{63}$ Indeed, by lowering the requirement on the first branch of the test from establishing a bona fide case (Justice von Finckenstein's threshold) to establishing a bone fide claim, the Court of Appeal gave even greater priority to intellectual property rights (and other civil claims) over privacy interests - with the result that ISPs, whatever their contractual obligations to their clients, would be more frequently required to reveal their clients' identities in civil proceedings brought by third parties.

\section{INTELLECTUAL PROPERTY AND PROPERTY}

What is the nature of the interests that are declared by Justice Sexton to be competing for priority in society? He discusses intellectual property and property and he also describes both 'privacy concerns" 64 and 'public concerns for the protection of intellectual property rights'. ${ }^{65}$

It may be useful to begin first by setting aside the equation of intellectual property and property articulated by Justice Sexton. Copyright is intellectual property, not property. ${ }^{66}$ Mis-characterizing its essential nature will not assist

62 The majority was particularly leery of imposing obligations on ISPs (ibid.). The precedent created by the Federal Court of Appeal in $B M G v$. John Doe, if correct, can impose obligations on ISPs and does directly affect the ability of ISPs to guarantee confidentiality to their clients.

63 BMG FCA, supra note 2 at para. 42.

64 Ibid. (See also the opening quotation in this chapter.)

65 Ibid.

66 See, for example, W.A. Adams, 'Personal Property Law and Information Assets: Rehabilitation and Relevance,' (2002) 36 Canadian Business Law Journal 267. This perspective may be perceived to run counter to the argument made by Norman Siebrasse that, rather than attempting to balance dissemination and the incentive to create works through copyright law, copyright law should focus on ensuring that property rights are clearly defined: Norman Siebrasse, 'A Property Rights Theory of the Limits of Copyright' (2001) 51 University of Toronto Law Journal 1. On the other 
with the resolving of the important questions facing lawmakers. ${ }^{67}$ Daniel Gervais has recently pointed out that there are both economic and instrumentalist justifications for copyright and rights-based justifications for copyright made - but '[t]rying to squeeze copyright on one side of that philosophical fence is incorrect in historical perspective, both in common law and civil law jurisdictions' ${ }^{68}$

It has been widely acknowledged that copyright, in its current form in Canada, is a purely statutory system. ${ }^{69}$ Further, in s. 3 of the Canadian Copyright Act, it is made absolutely clear that rights exist for rights holders only in the whole or a substantial portion of works. Authors, therefore, do not have an exclusive or exclusionary right over their works - only rights over substantial portions or whole dealings with their works. Where insubstantial portions of their works are involved, authors and copyright holders have no interest. $^{70}$ Moreover, the holders of economic rights in copyright under Canadian law are only compensated if they have a right that would, without their consent, be infringed:

hand, his need to make the argument itself demonstrates that copyright, as a branch of intellectual property, cannot be considered pure property. See R.J. Roberts, 'Canadian Copyright: Natural Property or Mere Monopoly' (1979) 40 C.P.R. (2d) 33; Compo Co. v. Blue Crest Music Inc., [1980] 1 S.C.R. 357 at 373, Estey J.; Bishop v. Stevens, [1990] 2 S.C.R. 467 at 477.

67 It should be noted that there have been calls to create a property right in personal data. For example, James Rule and Lawrence Hunter, 'Towards Property Rights in Personal Data' in Colin J. Bennett \& Rebecca Grant, eds., Visions of Privacy: Policy Choices for the Digital Age (Toronto: University of Toronto Press, 1999) 168. It should also be noted that the authors do not discuss the relationship between this proposed property interest and existing interests in intellectual property.

68 Daniel Gervais, 'The Changing Role of Copyright Collectives' in Daniel Gervais, ed., Collective Management of Copyright and Related Rights (The Netherlands: Kluwer Law International, 2006) 3 at 6.

69 As Plowman J. writes in Universities of Oxford and Cambridge v. Eyre \& Spottiswoode Ltd., [1964] 1 Ch 736 at 750, [1963] 3 All E.R. 289 at 293, 'until 1709 [the Statute of Anne] private copyright did not exist.' And, explicitly, in 1911, the Imperial Copyright Act abolished any common law copyright: s. 31. This provision is carried forward in s. 89 of the current Canadian Copyright Act.

70 A point recognized by the Copyright Board in Application by Pointe- $a-$ Callière, Montreal Museum of Archeology and History for the Reproduction of Quotations (29 March 2004), Copyright Board Decision, online: <http://www.cbcda.gc.ca/unlocatable/other/1-b.pdf>, when the Board declined to give applicants licenses for unlocatable copyright holders that they were seeking because the Board found the use being contemplated was not one over which the copyright holders had rights. CCH Canadian Ltd. v. Law Society of Upper Canada, [2004] 1 S.C.R. 339 at para. $56[\mathrm{CCH}]$, 'if the amount taken from a work is trivial, the fair dealing analysis need not be undertaken at all because the court will have concluded that there was no copyright infringement' because, under s. 3, 'copyright subsists in every work or every substantial portion...'. 
It is an infringement of copyright for any person to do, without the consent of the owner of the copyright, anything that by this Act only the owner of the [economic] copyright has the right to do. ${ }^{71}$

This is far from vesting a property right in works. Indeed the Canadian Copyright Act embraces three independent sets of rights. Two of these systems of rights take the form of limited term monopolies ${ }^{72}$ emanating from the creation of works: the economic rights in copyright and the moral rights in copyright. The moral rights are inalienable interests held by the creators of works. ${ }^{73}$ The third set of rights is based on particular uses of information: this third set is the users' rights. The fair dealing exceptions under the Canadian Copyright Act are the cornerstone of this set of rights. ${ }^{74}$ As the Chief Justice expressed it, for a unanimous Supreme Court,

User rights are not just loopholes. Both owner rights and user rights should therefore be given the fair and balanced reading that befits remedial legislation. ${ }^{75}$

It is true that the Supreme Court has recently considered the role of licenses in the context of the Copyright Act and specifically approved the following explanation of the relationship between rights and permissions under the Act:

The 'grant of an interest' referred to in s. 13(4) [of the Copyright Act] is the transfer of a property right as opposed to a permission to do a certain thing. The former gives the licensee the capacity to sue in his own name for infringement, the latter provides only a defence to claims of infringement. ${ }^{76}$

\footnotetext{
71 Copyright Act, supra note 6, s. 27(1).

$72 \mathrm{Ibid}$. at s. 6. (Both sets of rights run for the life of the author plus approximately fifty years).

73 Ibid. at ss. 2, 14.1, 14.2, 28.1 and 28.2. (These rights in Canada include the
} rights to paternity and integrity as well as rights to determine with what the creator's work will be associated. While they can be waived, they cannot be assigned.)

74 Margaret Ann Wilkinson 'Filtering the flow from the fountains of knowledge: access and copyright in education and libraries' in Michael Geist, ed., In the public interest: the future of Canadian copyright law (Toronto: Irwin Law, 2005) 331. (The users' rights language of the Supreme Court of Canada is strong, rights-based language and offers a powerful alternative to the potential tyranny of rights holders' interests signalled by the mandatory language in the Berne Convention, NAFTA and TRIPS agreements. The Government may wish to bear in mind that a strong connection may be drawn between the rights-based language of the Supreme Court of Canada in this area and the right to freedom of expression, including rights to access information, under s. 2(b) of the Charter of Rights and Freedoms.)

$75 \mathrm{CCH}$, supra note 70 at para. 48, quoting with approval from David Vaver, Copyright Law (Toronto: Irwin Law, 2000) 171.

76 Robertson v. Thomson Corp., [2006] 2 S.C.R. 363 at para. 56, LeBel and Fish JJ., for the majority (quoting Ritchie v. Sawmill Creek Golf \& Country Club Ltd. 
However, this statement is specifically made with reference to certain economic rights granted under the Copyright Act. Failure to distinguish between various uses of expressions of facts and ideas (information), which are reserved to the holders of the economic rights in copyright under the Canadian Copyright Act, and the works associated with these economic copyright interests, or the facts and ideas lying behind the expressions, will distort the role and contribution of economic rights in copyright to society ${ }^{77}$ and eclipse the contribution of both moral rights under the Canadian Copyright Act and users' rights under the Canadian Copyright Act, such as fair dealing.

A key feature of intellectual property is that these devices carry with them aspects of public interest. In the Copyright Act, all three bundles of rights (the economic, the moral and the users') serve the public interest. Justice Binnie, writing for the majority in Théberge v. Galerie d'Art du Petit Champlain, emphasized that the Copyright Act provides 'a balance between promoting the public interest in the encouragement and dissemination of works of the arts and intellect and obtaining a just reward for the creator (or, more accurately, to prevent someone other than the creator from appropriating whatever benefits may be generated). ${ }^{78} \mathrm{He}$ went on to recognize the special - and limited nature of the economic copyright holders' rights under copyright:

The proper balance...lies not only in recognizing the creator's rights but in giving due weight to their limited nature. In crassly economic terms, it would be as ineffi-

(2004), 35 C.P.R. (4th) 163 (Ont. S.C.J.)). See also paras. 57-8 (the majority of the Court further held that 'the content of these licenses is a live issue that should go to trial... Parties are, have been, and will continue to be, free to alter by contract the rights established by the Copyright Act').

77 To consider meeting the information needs in a society one must factor in many who are not, and may never become, 'authors' within the meaning of the Copyright Act - but who are nonetheless communicators of ideas and facts. Abraham Drassinower has promulgated an interesting analysis, in various publications, that essentially reduces copyright players to authors and non-authors: see Abraham Drassinower, 'A Rights-Based View of the Idea/Expression Dichotomy in Copyright Law' (2003) 16 Canadian Journal of Law and Jurisprudence 3. He has been unable to extend his analysis to the patent arena (see Margaret Ann Wilkinson, 'National Treatment, National Interest and the Public Domain' (2003-2004) 1:1-2 University of Ottawa Journal of Technology Law 23) because not all non-patent holders can realistically be considered potential patent holders. That Drassinower cannot articulate his theory for patents may in fact be because the patent situation more clearly points out an essential weakness in the whole theory, even for the copyright context: not all nonauthors are potential authors - there is a class of non-authors who, nevertheless, are important information users and disseminators.

78 Théberge v. Galerie d'Art du Petit Champlain inc., [2002] 2 S.C.R. 336 at para. 30 [Théberge] [italics added], Tariff 22, supra note 50 at para. 40 . All but the italicized section is also restated and approved in $\mathrm{CCH}$, supra note 70 at para. 10. 
cient to overcompensate artists... as it would be self-defeating to under-compensate them...

Excessive control by holders of copyrights and other forms of intellectual property may unduly limit the ability of the public domain to incorporate and embellish creative innovation in the long-term interests of society as a whole, or create practical obstacles to proper utilization. ${ }^{79}$

The Chief Justice further expressed this concept in CCH v. Law Society of Upper Canada: 'the purpose of the copyright law was to balance the public interest in promoting the encouragement and dissemination of works of the arts and intellect and obtaining a just reward for the creator. ${ }^{80}$

Thus equating intellectual property rights such as copyright with property is not accurate, but perhaps more importantly, it does nothing to assist in the resolution of problems involving competing legal interests and, indeed, leads to mischaracterization of interests by obscuring such values as the encouragement and dissemination of innovations and works of the art and intellect.

\section{PRIVACY AND INTELLECTUAL PROPERTY}

Justice Sexton characterized the challenge before the court in BMG v. John Doe as one requiring consideration of privacy rights in light of intellectual property concerns - and gave intellectual property priority. However, in terms of 'privacy concerns', two different ideas occur in BMG v. John Doe. First, acknowledged in the agreement of the parties, are the statutory obligations imposed upon the ISPs under the PIPEDA. Second are notions of privacy that pre-date the coming into force of PIPEDA: 'the legitimate privacy concerns' referred to in the fifth branch of the test for granting equitable bills of discovery and now declared by Justice Finckenstein, approved by the Court of Appeal, applicable to applications under Rule 238 of the Federal Court.

Turning first to the statutory obligations, Justice von Finckenstein wrote his judgment, released on 31 March 2004, just months after the Personal Information Protection and Electronic Documents Act (PIPEDA) came into force in respect of businesses such as ISPs, on 1 January $2004 .{ }^{81}$ Indeed, up until 2000, no such legislation existed at all in the private sector in Canada (except in Quebec where the Act Respecting the Protection of Personal

79 Théberge, ibid. at paras. 31-2.

$80 \mathrm{CCH}$, supra note 70 at para. 23, McLachlin, C.J. (citing Théberge, supra note 78 at 335 , Binnie J.).

81 Personal Information Protection and Electronic Documents Act, S.C. 2000, c. 5 [PIPEDA], discussed in BMG FC, supra note 2 at paras. 38-40. 
Information in the Private Sector ${ }^{82}$ dates from 1993). The personal data protection aspects of PIPEDA came into force for federally regulated businesses (for example, shipping companies) and any inter-provincial transfers of information by Canadian businesses on 1 January 2001, ${ }^{83}$ except where the information involved was personal health information, ${ }^{84}$ but, as mentioned, by 1 January 2004, all private sector organizations engaged in 'commercial activities' in Canada were included in the regime ${ }^{85}$ (including those dealing with personal health information). ${ }^{86}$

Personal data protection is a statutory regime that has swept across Canada since 1977, when it was first introduced into the public sector in Part IV of the Canada Human Rights Act. ${ }^{87}$ It was later combined with the access to government information initiative, ${ }^{88}$ becoming, in 1982, the federal Privacy Act ${ }^{89}$ passed together with the federal Access to Information Act ${ }^{90}$ Similar legislation was passed in Quebec in the same year. ${ }^{91}$ Combined access and personal data protection legislation now governs the vast majority of public sector orga-

82 Act Respecting the Protection of Personal Information in the Private Sector, R.S.Q. c. P-39.1.

83 PIPEDA, supra note 81 at s. 30(1).

84 Ibid. at s. 30(1.1).

85 Ibid. at ss. 30(2), (2.1).

86 The federal government, for constitutional reasons, left room for, and indeed encouraged, provincial regulation of private sector activities - and some provinces have taken up this invitation. The federal legislation anticipates the passage of 'equivalent' provincial legislation, by providing that, once recognized as equivalent by the federal Cabinet, such provincial legislation will replace PIPEDA for provincial matters within that province (PIPEDA, supra note 81 at s. 26(2)(b)). Quebec's pre-existing Act respecting the protection of personal information in the private sector, supra note 82 has already been recognized by the federal government as equivalent to PIPEDA. Several other provinces have passed legislation for the private sector - but have not succeeded in persuading the federal government that the legislation is equivalent to PIPEDA (Alberta, Personal Information Protection Act, S.A. 2003, c. P-6.5 and British Columbia, Personal Information Protection Act, S.B.C. 2003, c. 63.) - thus organizations in those provinces must satisfy both regimes. Several other provinces have passed specific personal data protection legislation for the health sector. In Ontario's case, this legislation has been deemed equivalent to PIPEDA by the federal government. See, in this connection: Wil Peekhaus, 'Personal Medical Information: Privacy or Personal Data Protection?' (July 2006) 5:2 Canadian Journal of Law and Technology 87.

87 Canadian Human Rights Act, R.S.C. 1985, c. H-6.

88 In a unique move, the two separate statutes, now separately located and identified, were passed in one bill: Access to Information Act and Privacy Act, S.C. 1982, c. 111 .

89 Privacy Act, R.S.C. 1985, c. P-21.

90 Access to Information Act, R.S.C. 1985, c. A-1.

91 An act respecting access to documents held by public bodies and the Protection of personal information, R.S.Q. c. A-2.1. 
nizations. ${ }^{92}$ It must be noted, however, that personal data protection legislation in the private sector is not combined with access legislation.

This difference between public and private sector personal data protection legislation - that the former is invariably combined with access legislation but the latter never is - becomes important in examining one precedent discussed by both Justice Finckenstein and the Court of Appeal in BMG v. John Doe: Glaxo Wellcome PLC v. Minister of National Revenue. ${ }^{93}$ At the time of the Glaxo Wellcome case, Revenue Canada would indeed have been subject to public sector personal data protection legislation. ${ }^{94}$ However, as noted, all public sector institutions governed by personal data protection legislation are also subject to access legislation ${ }^{95}$ and, indeed, the Glaxo Wellcome decision stands for the proposition that a litigant seeking production of documents in

92 There are arguably 14 jurisdictions in Canada: the federal government, nine provinces and three territories (although technically territorial governments are subordinate to the federal government). Municipalities are subordinate to the legislatures of the provinces. In some provinces they are included in the personal data protection legislation that governs provincial organizations (Alberta, British Columbia, Quebec and Newfoundland) and in some cases provinces have passed separate legislation for them (Ontario and Saskatchewan). In other jurisdictions municipalities per se are not covered (New Brunswick, Nova Scotia, and Prince Edward Island). Thus the public sector legislation in force is as follows: Privacy Act, R.S.C. 1985, c. P-21 (Canada), Freedom of Information and Protection of Privacy Act, R.S.A. 2000, c. F-25 (Alberta), Freedom_of Information and Protection of Privacy Act, R.S.B.C. 1996, c. 165 (British Columbia), the Freedom of Information and Protection of Privacy Act, S.M. 1997, c.50 (Manitoba), Access to Information and Protection of Privacy Act, S.N.L. 2002, c. A-1.1 (Newfoundland and Labrador), Right to Information Act, S.N.B. 1978, c. R-10.3 (New Brunswick), Freedom of Information and Protection of Privacy Act, S.N.S. 1993, c.5 (Nova Scotia), Freedom of Information and Protection of Privacy Act, R.S.O. 1990, c. F.31 (Ontario), Freedom of Information and Protection of Privacy Act, S.P.E.I. 2001, c. 37 (Prince Edward Island), An Act Respecting Access to Documents Held By Public Bodies and the Protection of Personal Information, supra note 91 (Quebec), Freedom of Information and Protection of Privacy Act, S.S. 1990-91, c. F-22.01 (Saskatchewan), Access to Information and Protection of Privacy Act, S.N.W.T. 1994, c. 20 (Nunavut \& Northwest Territories), Access to Information and Protection of Privacy Act, R.S.Y. 2002, c. 1 (Yukon), Municipal Freedom of Information and Protection of Privacy Act, R.S.O. 1990, c. M56 (Ontario), Local Authority Freedom of Information and Protection of Privacy Act, S.S. 1990-91, c. L-27.1 (Saskatchewan). It also must be noted that in four provinces public health information has been moved to separate legislation: Health Information Act, R.S.A. 2000, c. H-5 (Alberta), Personal Health Information Act, C.C.S.M. c. P33.5 (Manitoba), Personal Health Information Protection Act, 2004, S.O. 2004, c. 3, Sch. A (Ontario) and Health Information Protection Act, S.S. 1999, c. H-0.021 (Saskatchewan).

93 Glaxo Wellcome PLC v. M.N.R. (1998), 81 C.P.R. (3d) 372 (F.C.A.) [Glaxo]

(Considered in BMG FCA, supra note 2 at para. 32).

94 Privacy Act, supra note 89.

95 Access to Information Act, supra note 90. 
the possession of a public sector institution governed by access legislation need not apply under the access legislation but can, instead, seek a court order for production. Justice Sexton cited the decision because the plaintiff obtained a disclosure order requiring Revenue Canada to identify certain importers who were alleged to have infringed its patents. However, personal data protection focuses exclusively on individuals, not corporate bodies, and is only relevant in the case of information about identifiable individuals - it has no application in the case of the identities of corporate persons. The identities of corporate persons were at issue in the Glaxo Wellcome case, not the identities of individuals, and the Federal Court of Appeal in that case, accordingly, was only considering the Access to Information Act, not the Privacy Act. ${ }^{96}$ The thrust of the Access to Information Act is in favour of public access to information held by public sector organizations - the opposite thrust of PIPEDA, which was the legislation applicable in the BMG v. John Doe case. Thus, the reliance placed upon the Glaxo Wellcome case by both courts, but particularly the Court of Appeal, in BMG v. John Doe is entirely misplaced.

Although related to the concept of privacy, personal data protection is not privacy legislation. It neither confers upon an organization subject to it the ability or duty to gather information from individuals nor prohibits an organization from gathering information from individuals. Rather than dealing with whether information can be gathered about individuals or from individuals, personal data protection statutes begin by regulating how information is to be gathered about individuals if the organization either needs or is mandated elsewhere to gather that type of information. That personal data protection legislation is not strictly privacy legislation is evidenced by the fact that the Organisation for Economic Co-operation and Development Guidelines, with which Canada's regimes deliberately concur, ${ }^{97}$ articulate a dual purpose: not only to protect personal information but also to ensure the free flow of data between countries. ${ }^{98}$

96 Glaxo, supra note 93 (note that the Privacy Act is not judicially considered).

97 Organisation for Economic Co-operation and Development, Guidelines on the Protection of Privacy and Transborder Flows of Personal Data (Paris, 1981) [OECD Guidelines]. Canada became a signatory in 1984. Canada's regimes are also designed to make Canadian organizations compatible with the EC, Directive 95/46/EC of the European Parliament and of the Council of 24 October 1995 on the protection of individuals with regard to the processing of personal data and on the free movement of such data, [1995] O.J. L.281/31. The EU has given this domestic directive an international application in that it prohibits those subject to its Directive from sharing information with organizations elsewhere who are not obliged to treat personal information in comparable ways.

98 Colin Bennet, Regulating Privacy: Data Protection and Public Policy in Europe and the United States (Ithaca: Cornell University Press, 1992) 136-140. See also OECD Guidelines, ibid. 
But privacy, as distinct from statutory personal data protection, clearly has a role to play in BMG v. John Doe: the fifth branch of the test for disclosure, which certainly predates personal data protection in Canada, concerns 'legitimate privacy concerns'. What are these concerns?

Privacy, since the late nineteenth century, has popularly come to be understood as 'the right to be let alone" 99 and there has been increasing debate about whether, and to what extent, it should be protected by law - even though it has become enshrined in international instruments (to which Canada is signatory). First, the Universal Declaration of Human Rights (1948) ${ }^{100}$ provides in Article 12 that:

No one shall be subjected to arbitrary interference with his privacy... Everyone has the right to the protection of the law against such interference or attacks. ${ }^{101}$

Second, Article 17 of the International Covenant on Civil and Political Rights $^{102}$ provides:

(1) No one shall be subject to arbitrary or unlawful interference with his privacy, family, home or correspondence, nor to unlawful attacks on his honour or reputation.

(2) Everyone has the right to the protection of the law against such interference or attacks.

These instruments do not provide definitions of the concept of privacy and the classic 'right to be let alone', involving the description of privacy as a right, goes beyond articulating the concept of privacy and makes a claim to legal, or at least normative, status. This, in turn, may obscure, rather than assist, the quest to understand the concept of privacy. A better conception might be 'the state of being let alone'. 103

\footnotetext{
99 Samuel Warren \& Louis Brandeis, 'The Right to Privacy' (1893) 4 Harv.L.Rev. 193 at 213.

100 Universal Declaration of Human Rights, GA Res. 217(III), UN GAOR. 3d Sess., Supp. No. 13, UN Doc. A/810 (1948) 71.

$101 \mathrm{Ibid}$. at Art. 27 contains provisions related to intellectual property: (1) Everyone has the right freely to participate in the cultural life of the community, to enjoy the arts and to share in scientific advancement and its benefits. (2) Everyone has the right to the protection of the moral and material interests resulting from any scientific, literary or artistic production of which he is the author.

102 International Covenant on Civil and Political Rights, 999 U.N.T.S. 171 (entered into force 1976), online: <http://www.unhchr.ch/html/menu3/b/a_ccpr.htm>.

103 Which concurs with the early usage of privacy recorded in the Oxford English Dictionary as dating from 1450: 'The state or condition of being withdrawn from the society of others, or from the public interest.'
} 
While personal data protection is confined by statute to information about an identifiable individual, ${ }^{104}$ privacy can embrace rights to refuse to divulge any information held by an individual that she or he desires to keep secret, including information about her or himself. ${ }^{105}$ Moreover, while personal data protection, as its name implies, encompasses only data issues, ${ }^{106}$ privacy encompasses concerns about a much wider range of interferences with the individual. ${ }^{107}$

Nonetheless, while in other societies, at other times, the value of privacy as it relates to personal information may not have been highly regarded, ${ }^{108}$ an individual's interest in personal information privacy has been enshrined in Canada as a value to be protected against government incursion. In the criminal context, the majority of the Supreme Court held:

In fostering the underlying values of dignity, integrity and autonomy, it is fitting that s. 8 of the Charter should seek to protect a biographical core of personal information which individuals in a free and democratic society would wish to maintain and control from dissemination to the state. This would include information which tends to reveal intimate details of the lifestyle and personal choices of the individual. ${ }^{109}$

Again in the criminal context, the Supreme Court held in 1990 that '[p]rivacy may be defined as the right of the individual to determine when, how, and to what extent he or she will release personal information'. ${ }^{110}$ In this context, the Court identified its notion of privacy with the context of personal information, thus limiting its conception of information privacy. Alan Westin, in the 1960s,

104 Privacy Act, supra note 89 at s. 3.

105 Margaret Steig, 'The Nineteenth-Century Information Revolution' (1980) 15 Journal of Library History 22 (Illustrates the attitude of early industrial British employers who considered information about their employees to be the private affair of the employer and therefore not to be made available to the government or anyone else).

106 That is, information contained in records.

107 The Canadian Charter of Rights and Freedoms, for example, does not contain a direct reference to privacy, but both s. 7 ('Everyone has the right to life, liberty and security of the person and the right not to be deprived thereof except in accordance with the principles of fundamental justice') and s. 8 ('Everyone has the right to be secure against unreasonable search or seizure') have been interpreted to protect Canadians against government incursion of privacy interests beyond informational privacy.

108 David Flaherty, Privacy in Colonial New England (Charlottesville, VA: University Press of Virginia, 1972) at 243-5. (Described the situation in the original New England colonies of America where the social consensus was that the individuals harbouring interest in being let alone were suspect.)

109 R. v. Plant, [1993] 3 S.C.R. 281 at para. 20, Justice Sopinka, speaking for Justices LaForest, Gonthier, Cory, Iacobucci, and then Chief Justice Lamer. Justice McLachlin (as she then was) dissented on other grounds.

110 R. v. Duarte, [1990] 1 S.C.R. 30 at para. 25. 
interpreted privacy in similar language, as including an 'informational right': a right of people and organizations 'to determine when, how, and to what extent information about them is communicated to others'. ${ }^{111}$ However, as then Chief Justice Lamer pointed out, in his dissent in Aubry v. Editions ViceVersa, there are additional limitations on the notion of constitutionally protected informational privacy in Canada:

the decisions of this Court relating to s. 8 [of the Charter] recognize that there is a fundamental difference between a person's reasonable expectation of privacy in his or her dealings with the state and the same person's reasonable expectation of privacy in his or her dealings with ordinary citizens... It would therefore be wrong to define the scope of the right to privacy between citizens solely on the basis of the decisions relating to $\mathrm{s}$. $8 \ldots$ the right to privacy can have a different scope in private law. ${ }^{112}$

\footnotetext{
111 Alan F. Westin, Privacy and Freedom (New York: Atheneum, 1967) at 7.

112 Aubry v. Editions Vice-Versa, [1998] 1 S.C.R. 591 at paras. 8-9 [Aubry]. A
} recent decision in the Ontario Superior Court of Justice has comprehensively considered the place of privacy under the Canadian Charter of Rights and Freedoms. In Cheskes et al v. A.G.(Ont.), [2007] O.J. no. 3515, 2007 CanLII 38387 (Ont. S.C.), released 19 September 2007, Justice Belobaba held that the disclosure provisions of Ontario's Adoption Information Disclosure Act, S.O. 2005, c.25, proclaimed in force 17 September 2007, as part of the Vital Statistics Act, R.S.O. 1990, c. V.4, as amended, violated s. 7 of the Charter and are invalid and are of no force or effect. In terms of this analysis, several aspects of Justice Belobaba's reasons are worth noting. First, while setting out ten background points on which the judgment is based, Justice Belobaba equates personal data protection legislation with privacy [at para.62] and cites the existence of personal data protection and personal data protection commissioners ['privacy commissioners'] as evidence that the protection of privacy is a fundamental value in modern democracies. Second, the breach of the Charter which Judge Belobaba finds occurred in this case is characterized [at para.91] as a breach of the right to liberty under s.7 of the Charter: 'I have found a breach of the right to liberty by focussing on the informational privacy interest and applying the reasoning in $R$. v. O'Connor [[1995] 4 S.C.R. 411 at para.120].' Justice Belobaba agrees with the analysis herein that 'there is no freestanding right to privacy in the Charter. If a right to privacy exists under the Charter, it has to be found in the provisions that touch on matters of individual autonomy.' [para. 79, footnote omitted]. It should be noted that the Ontario government has subsequently passed An Act to Amend the Vital Statistics Act in relation to adoption and to make consequential amendments to the Child and Family Services Act, 2008, S.O. 2008, c.15), which received Royal Assent 14 May 2008, by which, since adoptions prior to 2008 were under different premises with respect to privacy than the new 2008 provisions, adult adoptees and birth parents whose adoptions were registered in Ontario prior to 1 September 2008 can place a disclosure veto on their file, but, if they do so, they will be asked to provide medical history so that the birth relatives can obtain personal health information. In addition, adult adoptees and birth parents may continue to place a no-contact notice on their files 
Even in the context of the protection of personal information from government intrusion, the value of informational privacy has been recognized in many instances to be secondary to other interests. Indeed, the majority of the Supreme Court in R. v. Plant itself held that the accused's reasonable expectation of privacy was outweighed by the public interest in criminal enforcement in the situation at bar. Other examples of legislated incursions on informational privacy are the census legislation and income tax legislation, both of which have become very controversial, on privacy grounds. ${ }^{113}$

By contrast, although there is a recognition in Canada of at least some limitations on the ability of government to intrude into the lives of Canadians and disrupt their 'state of being alone', including situations involving information privacy, in the private sector, there is not a strong body of consistent jurisprudence establishing the existence of a tort of invasion of privacy. The Manitoba Court of Appeal, in 1986, stated:

It would appear that at common law the tort of violation of privacy in regard to disclosure of personal information has not been recognized in Canada. Neither counsel has supplied us with a case indicating that this tort has been recognized. Counsel for defendants states simply that the tort has not been recognized although recognized in the United States of America. This is certainly not a proper or adequate factual situation to develop new law on the tort of invasion of privacy rights at common law. ${ }^{114}$

In Ontario, in 1996, a case arose which the court of first instance decided on privacy grounds, Gould Estate v. Stoddart Publishing. ${ }^{115}$ But the decision of

113 There was a recent controversy in Canada about the full release of post-1911 census records: see Beatty v. Canada (A.G.) (2004), [2005] 1 F.C.R. 327, [2004] F.C.J. No. 1162. Beginning in 1911 the enumerators were required by Order-in-Council (31 March 1911 at 11) as follows 'The facts and statistics of the Census may not be used except for statistical compilations, and positive assurances should be given on this point if a fear is entertained by any person that they may be used for taxation or any other object.' There was no time limit placed upon this undertaking and so it clashed with the legislated time limits for personal data protection in the public sector (the Privacy Act and the Access to Information Act, infra) legislated by Parliament much later in the twentieth century. The result was An Act to Amend the Statistics Act, S.C. 2005 , c. 31 (introduced first through Senate) - whereby the censuses taken between 1910 and 2005 become public 92 years after the census - but beginning with the 2006 census, the individuals to whom the information relates in the census must consent to the release of their information after 92 years. In 2006, only 56\% consented, which raises concerns, especially amongst genealogists and historians (see Gregory Bonnell 'Canadians lose "crucial" pieces of historical information in 2006 census: expert' Canadian Press NewsWire (15 March 2007)).

114 Bingo Enterprises Ltd. v. Plaxton (1986), 26 D.L.R. (4th) 604 (Man. C.A.).

115 Gould Estate v. Stoddard Publishing Co. (1996), 31 C.C.L.T. (2d) 224 (Ont. 
that court was overturned in 1998 on appeal to the Ontario Court of Appeal. The Court of Appeal held that the case should be decided purely on copyright grounds. In a more recent Ontario decision, the court held that it was possible that a claim to privacy could be the subject of a successful lawsuit but the litigation never continued to trial. ${ }^{116}$

There is, however, legislation ${ }^{117}$ in four common law jurisdictions of Canada that gives individuals a right to sue for certain violations of privacy: Saskatchewan (1978), ${ }^{118}$ Manitoba (1987), ${ }^{119}$ Newfoundland (1990) ${ }^{120}$ and British Columbia (1996). ${ }^{121}$

Gen. Div.), rev'd (1998), 39 O.R. (3d) 545 (Ont. C.A.). (The facts in the case were challenging in terms of the claim to invasion of privacy: the person whose privacy was alleged to have been violated was the famous pianist Glenn Gould, who was dead before the litigation arose; the author of the published piece which was alleged to have violated the privacy interest, Jock Carroll, was also dead before the legislation arose; the litigation was being maintained by the estate of the musician and the publishers.)

116 Somwar v. McDonald's Restaurant of Canada Ltd. (2006), 79 O.R. (3d) 172 (Ont. S.C.J.).

117 Canada is a federated state and, under its constitution, legislative power was divided in 1867 between the provinces and the federal government according to enumerated headings (Constitution Act, 1867 (UK), 30 \& 31 Vict., c. 3, reprinted in R.S.C. 1985, App. II, No. 5). Naturally, given its nineteenth century origins, very few information topics are reflected in this list of powers - really only copyrights and patents (see Constitution Act, 1867, ibid., ss. 91(22) (23)). However, the provinces retained exclusive power to legislate in areas of 'purely local and private interest' (see Constitution Act, 1867, and also Re: Anti-Inflation Act, [1976] 2 S.C.R. 373 and R. v. Crown Zellerbach Canada Ltd., [1988] 1 S.C.R. 401). Matters that do not fall within provincial heads are legislated federally under the residual power stated in s. 91 (see Constitution Act, s. 91, where the opening words empower the federal Parliament 'to make laws for the peace, order, and good government of Canada, in relation to all matters not coming within the classes of subjects by this Act assigned exclusively to the Legislatures of the provinces...'). Constitutionally, there is little argument for federal legislative control over privacy since property and civil rights and matters of local concern were specifically allocated to the provinces and have typically been interpreted very broadly: Peter W. Hogg, Constitutional Law of Canada (Scarborough, Ont.: Carswell, 2006) 453. Privacy is generally considered as related to human rights as well as being a matter of local concern. On the other hand, personal data protection has been legislated by both the federal and provincial governments of Canada, as described elsewhere, as an adjunct to the named subject areas of power each level of government already has under the Constitution Act.

118 Privacy Act, R.S.S. 1978 , c. P-24, s. 2.

119 Privacy Act, R.S.M. 1987, c. P125, s. 2(1).

120 Privacy Act, R.S.N.L. 1990, c. P-22, s. 3.

121 Privacy Act, R.S.B.C. 1996, c. 373, s. 1. The original Privacy Act in British Columbia was the first in Canada, enacted in 1968 (S.B.C. 1968, c. 39). In J.M.F. v. Chappell, [1998] B.C.J. No.276, it was determined that in criminal proceedings (governed under the federal Criminal Code, R.S.C. 1985, c. C-46), civil rules such as those represented by the Privacy Act could not be in conflict and did not apply. 
Particularly in the first three of these provinces, the statutes are articulated in terms of a focus on particular situations: surveillance, eavesdropping, and certain itemized commercial situations. For example, in Saskatchewan:

s. 2 It is a tort, actionable without proof of damages, for a person wilfully and without claim of right, to violate the privacy of another person.

s. 3 Without limiting the generality of s.2, proof that there has been:

(a) auditory or visual surveillance of a person by any means including eavesdropping, watching, spying, besetting or following and whether or not accomplished by trespass;

(b) listening to or recording of a conversation in which a person participates, or listening to or recording of messages to or from that person passing by means of telecommunications, otherwise than as a lawful party thereto;

(c) use of the name or likeness or voice of a person for the purposes of advertising or promoting the sale of, or any other trading in, any property or services, or for any other purposes of gain to the user if, in the course of the use, the person is identified or identifiable and the user intended to exploit the name or likeness or voice of that person; or

(d) use of letters, diaries or other personal documents of a person; without the consent, express or implied, of the person or some other person who has the lawful authority to give consent is prima facie evidence of a violation of the privacy of the person first mentioned.

There appear to have been very, very few successful actions brought under any of these statutes. ${ }^{122}$

122 There have been a number of cases argued in British Columbia but most have been unsuccessful, at least on the Privacy Act claims. David v. McArthur (1969), 10 D.L.R. (3d) 250, rev'd (1970) 17 D.L.R. (3d) (B.C.C.A.) involved the activities of a private investigator hired by a husband to conduct surveillance of a wife. Belzberg $v$. British Columbia Television Broadcasting Ltd (1981) (unreported but described in the Silber case below) was a case in which a privacy claim was made in addition to a claim in trespass, over photographs of a front door taken and broadcast without permission. In Wooding v. Little (1982), 24 C.C.L.T. 37, [1982] B.C.J. No. 1422 (B.C.S.C.) (QL) invasion of privacy and libel were both claimed and qualified privilege was held to be a defence to both causes of action. Silber v. British Columbia Television Broadcasting System (1985), 25 D.L.R. (4th) 345 involved the filming and broadcasting of an individual in a parking lot, as Justice Lysyk said:

in the middle of the day, on a site open to unobstructed view from an adjoining heavily travelled thoroughfare, in a busy commercial neighbourhood. The property was private in the sense that the plaintiffs had the right to exclude trespassers from it, but Mr. Silber could hardly expect to enjoy a right of privacy with respect to what happened there because that was open for anyone happening by to see (para. 17).

In Insurance Corporation of British Columbia v. Somosh (1983), 51 B.C.L.R. 344, a counterclaim for invasion of privacy by defendants to an action by the insurer of an 
Quebec, Canada's civil law jurisdiction, by contrast, has enacted a provincial statute which it has entitled the Quebec Charter of Rights and Freedoms. ${ }^{123}$ In it, the province gives privacy its strongest and clearest legal expression in Canada: ${ }^{124}$

s. 4 Every person has a right to the safeguard of his dignity, honour and reputation

automobile against an owner and driver was successful. The main action was dismissed, but on the counterclaim, a private investigator's inquiries about the financial positions of the defendants were found to be invasions of privacy. On the other hand, in Rusche v. Insurance Corp. of British Columbia, [1992] B.C.J. No.87, 4 C.P.C. (3d) 12 (B.C. S.C.), a jury finding that there was no breach of the Privacy Act in the actions of private investigators was left undisturbed. In Milton v. Savinkoff, [1993] B.C.J. No. 2396 (B.C. S.C.), a woman did not succeed in her claim of violation of privacy having carelessly left photos of herself partially clothed in the defendant's jacket but objecting to their being distributed to another acquaintance. In Hollingsworth v. BCTV, a division of Westcom TV Group Ltd., [1998] B.C.J. No.2451, [1999] 6 W.W.R. 54, 59 B.C.L.R. (3d) 121, in an action founded also in libel, the British Columbia Court of Appeal held that the Privacy Act did not apply in a claim against BCTV. In St. Pierre v. Pacific Newspaper Group Inc., [2006] B.C.J. No. 259 (B.C. S.C.), the Vancouver Sun was exonerated from a claim under the Privacy Act, concerning publication of a photograph, on the grounds of consent (s. 2(2)(a)) although found liable for defamation. One successful case, Poirier v. Wal-Mart Canada Corp., 2006 BCSC 1138 involved photographs:

It is a tort, actionable without proof of damage, for a person to use the name or portrait of another for the purpose of advertising or promoting the sale of, or other trading in, property or services, unless that other ... consents to the use for that purpose (British Columbia Privacy Act, s. 3(2) cited in para. 74).

In that case, Wal-Mart was found to have violated its long-term employee's rights by posting the employee's name and photograph beside a message welcoming shoppers to a new Wal-Mart location. In an earlier case involving a photograph, a British Columbian court held that reproductions of a photograph of an unidentified torso did not violate the privacy rights of the model who posed for the photograph: Joseph $v$. Daniels (Brent Daniels Photography) (1986), 4 B.C.L.R. (2d) 239, 11 C.P.R. (3d) 544. In Manitoba, in 1988, an interlocutory injunction was granted on the grounds of either private nuisance or under the Privacy Act where the defendant was harassed by mail and telephone in Pateman v. Ross, [1988] 68 Man.R. (2d) 181, and in Ferguson v. McBee Technographics Inc. (1989), 24 C.P.R. (3d) 240 (Man. Q.B.), portions of an affidavit filed in a proceeding in slander and injurious falsehood were struck as inadmissible because they were based on conversations to which the affiant was not party and they therefore prima facie violated s. 3(b) of the Privacy Act and were not saved under s. 5(c) of the Act as 'reasonable, necessary for, and incidental to, the protection of the person, property or other interests'.

123 The Quebec Charter of human rights and freedoms, R.S.Q. c. C-12.

124 There is no exception in it for newspapers. 
s. 5 Every person has a right to respect for his private life

s. 9 Every person has a right to non-disclosure of confidential information

In 1998, a majority of the Supreme Court of Canada, on appeal from the Quebec Court of Appeal, ${ }^{125}$ reinforced that strong privacy protection in Aubry v. Editions Vice-Versa. ${ }^{126}$

Looking only at the chequered patchwork of privacy protection in Canada, especially in common law Canada, it may not be surprising that Justice Sexton felt that 'privacy concerns...must yield to...intellectual property rights...' 127 - but is there another approach to consider in the BMG v. John Doe scenario in evaluating 'privacy concerns'?

\section{THE ROLE OF CONFIDENTIALITY IN PRIVACY AND PERSONAL DATA PROTECTION}

It is interesting that the information privacy right in Quebec is framed in terms of non-disclosure of confidential information: in terms of confidentiality and not in terms of personal information. Justice La Forest, in the criminal context in 1988, quoted with approval from a 1972 federal government report: 'This notion of privacy derives from the assumption that all information about a person is in a fundamental way his own, for him to communicate or retain for himself as he sees fit.' ${ }^{128}$ But Justice La Forest then went on to say:

In modern society, especially, retention of information about oneself is extremely important. We may, for one reason or another, wish or be compelled to reveal such information, but situations abound where the reasonable expectations of the individual that the information shall remain confidential to the persons to whom, and restricted to the purposes for which it is divulged, must be protected. ${ }^{129}$

\footnotetext{
125 Aubry, supra note 112.

126 Ibid., L'Heureux-Dubé J., Bastarache J. for the majority opinion, Gonthier J., Cory J., and Iacobucci J., concurring, Major J., and Lamer C.J.C., dissenting. Both Justices Lamer and Major dissented because there was no evidence of damages - but Chief Justice Lamer went on to dissent saying the right to privacy must be given a different scope in dealings between private parties than it is in dealings between individuals and government. Thus in the civil context of Ms Aubry's complaint, he would have required that the defendants in the case had committed a fault before giving the plaintiff Ms Aubry redress.

127 Ibid. at para. 41, quoted above.

128 R. v. Dyment, [1988] 2 S.C.R. 417 at para. 22 (citing Canada, Report of the Task Force established by the Department of Communications/Department of Justice, Privacy, and Computers (Ottawa: Information Canada, 1972) at 13).

129 Ibid.
} 
Canadian criminal law has, for some time, created legal protections of confidences for Canadians who choose to disseminate information, in such offences as s. 183 prohibiting the interception of private communications 'made under circumstances where it is reasonable for the originator to expect that [the communication] will not be intercepted by any person other than the person intended by the originator thereof to receive it...'130

In the civil context, there have long been particular legally recognized duties of confidence and the courts have imposed penalties upon confiders for breach of their duties in cases where the individual whose confidence had been broken sued. The courts in these cases have focussed on the relationship between the parties rather than the subject matter of the confidence. The legal protection of these information exchanges has been about confidentiality, not privacy. Since the late 1980s Canadian courts have continually expanded their protection of confidences, particularly in the commercial context, to the point now where the action for breach of confidence embraces situations far wider than just those involving information exchanges between or about individuals. ${ }^{131}$ Since the late 1980 s in Canada, the courts have recompensed the confider for a breach:

(1) if the information is secret;

(2) if the information was imparted in confidence, and

(3) if the information is such that it would save the confidante time, energy and expense and is used in an unauthorized fashion to the detriment of the confider. ${ }^{132}$

It should be noted there is no apparent public participation in this area. In patent, the public is guaranteed the right to inspect the innovations patented; ${ }^{133}$ in copyright there is the public's right to the free circulation of ideas and facts as well as users' rights. ${ }^{134}$ And in both cases, the monopolies given the economic rights holders are temporally limited. As the intellectual property device of protection of confidential information is developing, the public has no right of access to the subject matter of the secret, in any form, ever (there is no time limit to the monopoly of the confider on the secret). ${ }^{135}$

130 Criminal Code, supra note 121, s. 183.

131 Lac Minerals Ltd. v. International Corona Resources Ltd., [1989] 2 S.C.R. 574, [1989] S.C.J. No. 83; Cadbury Schweppes Inc. v. FBI Foods Ltd., [1999] 1 S.C.R. 142.

132 Lac Minerals Ltd. v. International Corona Resources Ltd., ibid.

133 Patent Act, R.S.C. 1985, c. P-4, s.10.

134 Discussed more fully below.

135 And because this is not an area of legislative law, there is no possibility of testing this legal development against the Canadian Charter of Rights and Freedoms (specifically, s. 2(b) the right to freedom of expression, which includes access). 
Breach of confidence has gradually entered into the arena of international trade agreement. The fullest expression of obligations concerning confidential information is found in the TRIPS Agreement: 136

Natural and legal persons shall have the possibility of preventing information lawfully within their control from being disclosed to, acquired by, or used by others without their consent in a manner contrary to honest commercial practices so long as such information:

(a) is secret in the sense that it is not, as a body or in the precise configuration and assembly of its components, generally known among or readily accessible to persons within the circles that normally deal with the kind of information in question;

(b) has commercial value because it is secret; and has been subject to reasonable steps under the circumstances, by the person lawfully in control of the information, to keep it secret. ${ }^{137}$

Both Kim Scheppele and Elizabeth Neill have published doctoral dissertation work focussing on definitional issues germane to any attempt to draw distinctions between notions of privacy, personal data protection and confidential information. In Legal Secrets, Scheppele ${ }^{138}$ has described an analytic framework which would identify the protection described in R. v. Plant as legal protection for direct transmission of 'secrets' from one individual (A) to another (B: the government). Scheppele treats as 'serial secrets' all secrets that have already moved from their original confider (A) to a confidante (B) where issues have arisen concerning further dissemination from that confidante (B) to another (C). She would place all such secrets under the rubric of 'confidentiality' rather than privacy. Neill, ${ }^{139}$ in Rites of Privacy and the Privacy Trade, also wrestled with these issues and argued for a conception of privacy as an

136 Member countries, including Canada, are limited in the exceptions they can create to those permitted under Article 13: 'Members shall confine limitations or exceptions to exclusive rights to certain special cases which do not conflict with a normal exploitation of the work and do not unreasonably prejudice the legitimate interests of the right holder.'

137 Trade-Related Aspects of Intellectual Property Rights Agreement (1994), 33 I.L.M. 1197, section 7, art. 39 [TRIPS]. The North American Free Trade Agreement Between the Government of Canada, the Government of Mexico and the Government of the United States, 17 December 1992, Can. T.S. 1994 No. 2, 32 I.L.M. 289 (entered into force 1 January 1994) [NAFTA] also contains obligations for Canada, the United States and Mexico in this area, providing that trade secrets shall be protected if they are secret, are of actual or potential commercial value and the confider has taken reasonable steps to keep them secret - see Articles 1711 (1), (2) \& (3).

138 Kim Lane Scheppele, Legal Secrets: Equality and Efficiency in the Common Law (Chicago: University of Chicago Press, 1988).

139 Elizabeth Neill, Rites of Privacy and the Privacy Trade: On the Limits of Protection for the Self (Montreal \& Kingston: McGill-Queens University Press, 2001). 
extension of our 'sacred selves'. Her argument is that, in imparting information under circumstances of confidentiality, an individual is extending the circle of the self to deliberately embrace other individuals - in the expectation of continued privacy. Neill specifically distinguishes her conception of the boundaries of privacy, which would generally include personal confidential relationships, from personal data protection, which she argues falls outside privacy. ${ }^{140}$ While extending the legal remedy of breach of confidence to the corporate commercial environment might be argued to be an extension of privacy values to corporations (who are, after all, legally endowed with capacity as persons), such an extension would be an anathema to Neill's perspective on privacy. It seems far more persuasive that this extension of the law of breach of confidence is one that clearly illustrates the conceptual differences between confidentiality and privacy.

Organizations that fall under personal data protection regimes are required to adhere to the dictates of the legislation so long as the information they hold continues to be identified with an individual. This responsibility arises and continues whether or not the individual subject is even aware either of the information's existence within that organization or of the contents of that information. Moreover, in virtually all Canadian jurisdictions, this responsibility continues for a number of years after the death of the subject individual. ${ }^{141}$ These characteristics of personal data protection differentiate it from

140 From the point of view of creating consistent information policy across Canada, Scheppele's conception, which distinguishes privacy and confidentiality, may be more useful - and, indeed, her approach may actually strengthen Neill's argument that personal data protection does not form a part of privacy policy. However, in the context of this discussion, since the ISPs had confidentiality agreements with their subscribers, Neill's conception would focus even greater attention on the implications of those arrangements.

141 The federal government, in the Privacy Act, supra note 89, protects personal information held by the governed public sector organizations for 20 years following death (s. 3 'personal information' (m)) whereas, under PIPEDA, supra note 81, it protects an individual's information held by private sector organizations either until 20 years after death or until 100 years after the document was created, whichever is the shorter (ss. 7(3)(h)(i), (ii)). British Columbia's legislation also operates with a 20 years after death time frame (Freedom of Information and Protection of Privacy Act, R.S.B.C. 1996, c. 165, s. 22(4) taken together with s. 36 (c)) and Nova Scotia's legislation is similar (Freedom of Information and Protection of Privacy Act, R.S.N.S. 1993, c. 5, s. 20(4) taken together with s. 30(c)). Newfoundland's legislation operates to protect information for 20 years after a person's death or for 50 years after the document was created, at least where the information is held in archives (Access to Information and Protection of Privacy Act, R.S.N.L. 2002 c. A-1.1, s. 42(c),(d)). Alberta and Saskatchewan protect personal information until 25 years after the individual's death (Freedom of Information and Protection of Privacy Act, R.S.A. 2000, c. F-25, s. 17(2)(i), the Local Authority Freedom of Information and Protection of Privacy 
legislation and common law which have arisen in defence of privacy rights. Personal data protection statutes artificially limit the abilities of the organizations governed by them because they generally prohibit collection of information about individuals from sources other than those individuals. Though digitization and the internet increasingly make available information about various people, organizations subject to personal data protection legislation must often ignore available sources of information and limit their access to information about identifiable individuals to seeking information from those individuals personally. Organizations subject to these statutes, even having properly accessed and collected information about identifiable individuals, are also limited by the legislation in the uses to which the collected information can be put. Thus these statutes, since they do not deal with the right to require an individual to disseminate information to particular organizations, but do limit the scope of the organization's abilities to use the information collected from individuals about themselves and prohibit its further dissemination except in very strict circumstances, appear to be extensions of the law of confidentiality, rather than privacy statutes. These laws mandate a relationship of confidence between individuals providing information about themselves to organizations and the affected organizations. ${ }^{142}$ The individual's entitlement

Act, R.S.S. 1990-91, c. L-27, 1 s. 29(1), the Freedom of Information and Protection of Privacy Act, R.S.S. 1990-1991, c. F-22.01, s. 30(1)). Prince Edward Island's legislation generally protects personal information for 25 years after death (Freedom of Information and Protection of Privacy Act, R.S.P.E.I., c. F-15.01, s. 15(2)(i)). Ontario protects personal information until 30 years after death (Freedom of Information and Protection of Privacy Act, R.S.O. 1990, c. F.31, s. 2(2); Municipal Freedom of Information and Protection of Privacy Act, R.S.O. 1990, c. M.56, s. 2(2)) and Quebec does the same, unless the record is over 100 years old (An Act respecting the protection of personal information in the private sector, supra note 82, s. 18.2.). Manitoba, on the other hand, protects information only until 10 years after an individual's death (the Freedom of Information and Protection of Privacy Act, C.C.S.M. 1997, c. F175 1997 s. 17(4)). New Brunswick's legislation contains no term of protection but appears to leave the matter open to regulation (Protection of Personal Information Act, S.N.B. c. P-19.1, s. 7).

142 Viewing personal data protection as statutorily created relationships of confidence, rather than fundamental privacy protection, may help to explain certain decisions of governments to make public information which would otherwise fall under personal data protection. One might point to the Ontario government's recent decisions to protect participants in adoptions before September 2008 from disclosure of their identities while requiring that adoptions from now on are subject to disclosure, albeit limited (see supra, note 112). The Ontario legislature took this action over the objections of the Ontario Privacy Commissioner (Office of the Privacy Commissioner of Ontario, News Release, 'Controversial adoption disclosure bill faces final vote but much needed protection missing (21 October 2005), online: $<\mathrm{http} / / /$ www.ipc.on.ca/ index.asp?layid=86\&fid1=418>). Neither she nor any other can appeal to the Canadian Charter of Rights and Freedoms to insist upon privacy 
to confidentiality in information supplied to organizations is limited under this legislation to information that is, and remain, identified with that individual personally. This is a much narrower scope of protection for confidences than is available in other areas of law providing legal protection for confidences. The narrow focus of this particular legal protection for confidentiality, limited as it is to confidences involving subject matter identified with the individual confider, is probably the source of much of the conceptual confusion between personal data protection legislation and privacy concepts. ${ }^{143}$

Moreover, it must be recalled that Canada's obligations under the $O E C D$ Guidelines are intended not only to protect personal information, but also to ensure the free flow of data between countries. One of the policy reasons that information about identifiable individuals held by affected organizations is to be gathered from those individuals directly is presumably to ensure integrity

protection for the parents (mothers) who put these children up for adoption years ago with assurances of privacy. Other examples of legal initiatives that counter the notions of privacy as a constitutional right are various provincial salary disclosure laws (in Ontario, see the Public Sector Salary Disclosure Act, 1996, S.O. 1996, c. 1, Sch. A, which requires that all employees making over $\$ 100,000$ per year, and their exact salaries, be published by public sector institutions annually; in Nova Scotia, see Ministerial Education Act Regulation 80/97, as amended up to N.S. Reg. 120/2006, concerning annual reporting of school board salaries, made under s. 145 of the Education Act, S.N.S. 1995-96, c.1).

143 This confusion has only been exacerbated by the decision of the Supreme Court in H.J. Heinz, Co. of Canada Ltd. v. Canada (Attorney General), [2006] 1 S.C.R. 441, [Heinz cited to S.C.R], where the majority of the Court held that the 'privacy' right under personal data protection legislation can be exercised on behalf of individuals by corporations. Personal data protection legislation carefully distinguishes between the rights under these statutes given to 'individuals', rather than legal 'persons' (in order to exclude corporate 'persons' from the direct ambit of personal data protection), and those rights given to 'third parties' - corporations, companies, and businesses (which have their own exemptions and protections). The minority in Heinz believed that corporate parties should be limited to claiming the exemptions specifically targeted for them. The majority permitted Heinz to invoke personal data protection exemptions to the federal access legislation in order to block release of information to a requestor. The individuals identified in the disputed information were not party to the litigation. Not only does the decision greatly enhance the ability of corporations to censor the public discourse, it distorts the purpose of the personal data protection regimes by wresting some control of personal information away from individuals and putting it back into the hands of corporations. The Court used the vocabulary of privacy throughout the judgment. If the Court had conceptualized the problem in terms of a legislated confidence between an identified individual and the public sector organization holding the data, it is submitted that it is less likely that the majority would have acceded to the request of a third party corporation to represent the interests of the confider individual, without notice to the individual concerned, and step into the shoes of the confider to insist that the confidante government organization not divulge the information to a requestor. 
in the data. This perspective is reinforced by the provision in these statutes requiring the affected organizations to either correct information held by identifiable individuals when an error is pointed out by the individual concerned or, at least, to keep a record of disagreement which reveals the related information provided by the subject which differs from the previously held information recorded by the organization. These provisions of personal data protection legislation cannot be interpreted as part of the concept of privacy. They provide a function in information terms that has long been provided by the law of defamation in situations where information about individuals is published. Libel law does not protect individual privacy - it does, however, protect individual reputations by limiting the publication of false information about individuals (where the individual is injured by the falsity) and, at the same time, provides protection for the integrity of published information about individuals. Personal data protection statutes provide the same functionality, ensuring data integrity, and thus contribute to the efficiency and effectiveness of flows of information between countries. This function of personal data protection is quite unrelated to notions of privacy.

Thus it would seem that Justice Sexton's characterization of the 'concerns' involved in the $B M G$ v. John Doe case as 'privacy concerns' swept together a complex set of separate considerations involving personal data protection and confidential relationships. Juxtaposing such a set of complex concepts against the complex set of concepts which is intellectual property cannot lead to a clear resolution of any particular challenging situation - instead each situation must be fully analyzed in light of specific intellectual property interests and 'privacy concerns' actually at issue.

\section{REVISITING BMG v. JOHN DOE}

It will be recalled that the parties in $B M G v$. John Doe agreed 'an ISP by virtue of s. 7(3)(c) of PIPEDA may disclose personal information without consent pursuant to a court order'. The relevant section reads:

(3) For the purpose of clause 4.3 of Schedule 1, and despite the note that accompanies that clause, an organization may disclose personal information without the knowledge or consent of the individual only if the disclosure is

(c) required to comply with a subpoena or warrant issued or an order made by a court, person or body with jurisdiction to compel the production of information, or to comply with rules of court relating to the production of records.

Clause 4.3 of Schedule 1 deals with 'Principle 3 - Consent' and provides that ' $[t]$ he knowledge and consent of the individual are required for the collection, use, or disclosure of personal information, except where inappropriate'. 
Records are defined under PIPEDA ${ }^{144}$ and do not include records that an organization would have to create - so, it would appear, on the same logic as Justice Sexton applied in considering Rule 233, ${ }^{145}$ that s. 7(3) of PIPEDA in this case would only apply in respect of the production of information (and not in terms of compliance with rules of court relating to the production of records) since there were no extant records at issue here. So the question would be whether the court had jurisdiction to compel the production of information. ${ }^{146}$

And this leads back to the realization that the only jurisdiction that the court had in this case to compel the production of information was a jurisdiction that includes consideration of whether the public interests in favour of the disclosure outweigh the legitimate privacy concerns.

So the key question becomes whether there is a public interest in favour of disclosure to the plaintiffs in this copyright infringement proceeding that outweighs the legitimate privacy concerns of the potential defendants. If legitimate privacy concerns prevail, then there is no jurisdiction in the court to compel production of this information and the provisions of $\mathrm{s}$. 7(3) of PIPEDA, the data protection legislation dictating the terms of a confidential relationship between the ISPs and their customers, would require the ISPs to keep that information confidential.

This is a different approach from that taken by Justice Sexton in his analysis in BMG v. John Doe. Justice Sexton explicitly equates consideration of the privacy interests at stake in his consideration of the fifth criterion (for considering compelling disclosure of the identities at issue) with a consideration of PIPEDA: 'Privacy rights are significant and they must be protected. In order to achieve the appropriate balance between privacy rights and the public interest in favour of disclosure, PIPEDA provides protection... ${ }^{147}$ At this point Justice Sexton's analysis became completely circular: PIPEDA permits disclosure if

144 PIPEDA, supra note 81, s. 2 ('Record' includes any correspondence, memorandum, book, plan, map, drawing, diagram, pictorial or graphic work, photograph, film, microform, sound recording, videotape, machine-readable record and any other documentary material, regardless of physical form or characteristics, and any copy of any of those things).

145 BMG FC, supra note 2 at para. 15 (Justice von Finckenstein held that only Rule 238 could be relevant to the outcome of this motion because under Rule 233 there would have to be a relevant document in existence and, in this case, any such document would have to be created).

146 An act respecting access to documents held by public bodies and the Protection of personal information, supra note 91, ss. 18-26 (This provision does not appear to exist in the Quebec statute governing the private sector; sections governing communication to third persons).

147 BMG FCA, supra note 2 at para. 38. 
there is a court order and the court used PIPEDA to determine whether there ought to be a court order - which inevitably led to a conclusion that there ought to be a court order - the conclusion Justice Sexton reached. ${ }^{148}$

It is not surprising, given his approach, that Justice Sexton then stated that 'privacy concerns may be met if the court orders that the user only be identified by initials, or makes a confidentiality order' ${ }^{149}$ - but under personal data protection legislation, including PIPEDA, the only actions contemplated are either the release or the withholding of a record - there is no provision for qualified release of the type envisioned by Justice Sexton. And even from a privacy perspective, rather than that of personal data protection legislation, the use of initials or a confidentiality order would not save the alleged infringer from public notoriety, it would not protect the alleged infringer from the lawsuit or from the plaintiffs having knowledge of his identity or home computer habits.

\section{THE PUBLIC INTEREST}

Since PIPEDA governs the information being sought in this application, by virtue of its being held by ISPs, the overriding public interest, as expressed by Parliament for the public, in the situation before the courts in BMG v. John Doe, then, must be the purpose for PIPEDA:

to establish rules [for organizations engaged in commercial activities]...in a manner that recognizes the right of privacy of individuals with respect to their personal information... and the need of [such] organizations [for] personal information for purposes that a reasonable person would consider appropriate ${ }^{150}$

Parliament has tempered this right to privacy and the needs of the organizations governed by PIPEDA through the inclusion of certain exceptions in the legislation. It is true that, as agreed by the parties in $B M G$ v. John Doe, one of these exceptions to the right to privacy in PIPEDA is the requirement that a custodial organization disclose personal information where required by court order. ${ }^{151}$ But when asking, in considering the question of disclosure under the five part test under the Federal Court Rule 238, whether the 'public interests in favour of disclosure' outweigh 'the legitimate privacy concerns', it must be borne in mind that there is, just since 2004, a clear articulation against disclo-

\footnotetext{
$148 \quad$ Ibid. at para. 42.

149 Ibid. at para. 45.

150 PIPEDA, supra note 81, s. 3.

151 Ibid. at s. 7(3)(c).
} 
sure of personal data held by private sector organizations in Canada in legislation. Rather than outweighing legitimate privacy concerns, this legislation explicitly articulates those concerns as a part of its raison d'être.

Justice von Finckenstein ${ }^{152}$ and Justice Sexton, for the Court of Appeal, cited a number of cases in support of the proposition that various public interests in favour of disclosure in civil proceedings had outweighed legitimate privacy concerns in the past. However, all of these cases arose prior to the full implementation of PIPEDA in the private sector. ${ }^{153}$ Justice von Finckenstein noted Ontario First Nations Limited Partnership v. John Doe, ${ }^{154}$ Canadian Blood Services/Société du Sang v. John Doe, ${ }^{155}$ Wa'el Chehab v. John Doe, ${ }^{156}$ Kibale v. Canada, ${ }^{157}$ Loblaw Companies Ltd v. Aliant Telecom Inc. and Yahoo. ${ }^{158}$ The Federal Court of Appeal in BMG v. John Doe particularly picked up on and noted the Loblaw case, where Rule 32.12 of the New Brunswick Rules of Court was used to compel production of the identity of someone who sent an e-mail spreading confidential information around the Loblaw operation. ${ }^{159}$ Irwin Toy v. Doe, ${ }^{160}$ also cited by both courts, was a 2000

152 BMG FC, supra note 2 at para. 41.

153 Loblaw Companies Ltd. v. Aliant Telecom Inc., [2003] N.B.J. No. 208 (N.B.Q.B.) (QL) might have concerned PIPEDA even though it was heard prior to 1 January 2004 because Aliant Telecom operated in the federally regulated telecommunications environment (in close association with Bell Canada), and was governed by PIPEDA after 2001 - but no personal data protection legislation was considered in the order. The Loblaw decision refers to Re Johnston and Frank Johnston's Restaurants Limited, [1980] P.E.I.J. No.34 which also pre-dates any relevant personal data protection legislation. The Ontario Court of Appeal in Straka v. Humber River Regional Hospital (2000), 51 O.R. (3d) 1 specifically pointed out that the Ontario Freedom of Information and Protection of Privacy Act did not apply to hospitals and could not be relevant to that case (at para. 33). Therefore the court concluded that the applicant could not be granted access to a reference letter written about him. Now, hospitals in Ontario fall under the Personal Health Information Protection Act, 2004, S.O. 2004, c. 2, Sch. A. However, whereas under s. 2 of the federal Privacy Act, 'the views or opinions of another individual about the individual' are an element of an individual's own 'personal information' and therefore the letter of reference at issue in Straka would be considered information about the applicant to be disclosed (as under other public sector personal data protection in Canada and for federally regulated private sector enterprises governed by PIPEDA), Ontario's Personal Health Information Protection Act does not apply to employee information (see s. 4(a)).

154 (3 June 2002), (Ont. S.C.J.).

155 (17 June 2002), (Ont. S.C.J.).

156 (3 October 2003), (Ont. S.C.J.).

157 [1991] F.C.J. No. 634 (F.C.) (QL).

158 Supra note 153.

159 BMG FCA, supra note 2 at para. 27.

160 Irwin Toy v. Doe (2000), 12 C.P.C. (5th) 103 (Ont. S.C.J.) at para. 37. See also $B M G F C$, supra note 2 at para. 41 . 
case, decided at a time when personal data protection in common law Canada applied only to public sector organizations. ${ }^{161}$ The Federal Court of Appeal picked up on and noted this case, decided under Rules 30.10 and 31.10 of Ontario's Rules of Civil Procedure, and holding that a third party could be compelled to produce the identity of senders of e-mail from ISPs in a defamation suit. ${ }^{162}$ When these cases were decided, 'the public interests in favour of disclosure' might have been properly said to 'outweigh the legitimate privacy concerns' because there was no personal data protection regime in the private sector in common law Canada. However, in the circumstances of BMG v. John Doe, there is a personal data protection regime in place in Canada in the private sector - that clearly establishes a public interest in personal data protection - and thus renders these previous decisions inapplicable to the analysis that should have been undertaken by the courts in BMG v. John Doe. Were it otherwise, if the Court of Appeal in BMG v. John Doe is correct, then ISPs will be ordered to identify individuals in any case where a plaintiff can establish a civil claim, not even a prima facie case, against those individuals. There is surely no qualitative difference between the civil claims of a plaintiff for copyright infringement and those of a plaintiff in any other civil proceedings, for example in divorce proceedings or a debtor-creditor issue. One might expect those seeking personal information about others to launch suits that they might not otherwise pursue because of the information that could be made available in preliminary proceedings. And the 'protection' of PIPEDA would be rendered unstable, to say the least. ${ }^{163}$ At any time an individual might discover that another had enough of a claim against her or him, in at least one area of law, to render the confidentiality of communications between that individual and her or his ISP defunct. ${ }^{164}$

161 Except in Quebec, Canada's only civil law jurisdiction, where An Act Respecting the Protection of Personal Information in the Private Sector, supra note 82, came into force in 1994.

162 BMG FCA, supra note 2 at para. 27.

163 Jane Bailey's quite different analysis of the BMG v. John Doe case, in a comparative context comparing the United States and Canada ('The Substance of Procedure: Non-Party Disclosure in the Canadian and U.S. Online Music Sharing Litigation' (2006) 43 Alberta L.R. 615), leaves her with much the same concern about privacy. She finds that 'If anything, Canada should consider strengthening protections for online privacy in the civil non-party disclosure process' (at para. 5) and 'the Court risks its procedures being used as a tool to exacerbate existing inequalities in resources between the music industry and those against whom they seek to make claims' (at para. 69).

164 It would seem that this might raise concerns in the context of Canada's international obligations under TRIPS and NAFTA because, in addition to the information concerning customers' personal data raising issues in the realm of personal data protection, it could lead to breaches of confidence 'contrary to honest commercial practices'. 
What then are the 'public interests in favour of disclosure'? PIPEDA legislates those interests in disclosure that transcend personal data protection: they are laid out in s. 7(3) of the Act (which makes reference to the accompanying provisions from Schedule 1 to the Act). They are subsections relating to Canadians' overriding interest in law enforcement:

...an organization may disclose personal information without the knowledge or consent of the individual only if the disclosure is

(c) made to a government institution or part of a government institution that has made a request for information, identified its lawful authority to obtain the information and indicated that

(i) it suspects that the information relates to national security, the defence of Canada or the conduct of international affairs,

(ii) the disclosure is requested for the purpose of enforcing any law of Canada, a province or a foreign jurisdiction, carrying out an investigation relating to the enforcement of any such law or gathering intelligence for the purpose of enforcing any such law, or

(iii) the disclosure is requested for the purpose of administering any law of Canada or a province; ${ }^{165}$

Nowhere in PIPEDA are the interests of private litigants, or those of intellectual property rights holders, generally placed ahead of personal data protection interests. How then can it be said that 'public interests in favour of disclosure...outweigh the legitimate privacy concerns' in the BMG v. John Doe litigation?

In this context, then, properly weighing the public interest in privacy against the public interest in private litigation protecting copyright interests must be revisited: Justice Sexton's consideration of the social importance of intellectual property rights must also be revisited.

The answer to the question of whether there is a public interest in assisting private litigants to pursue their remedies under the Copyright Act must be yes - not because of the nature of these rights as property rights but because of their nature as legislated intellectual property rights. But where that interest in assisting private litigants to pursue their remedies involves disclosure of personal data protection held by private sector third parties engaged in commercial activities, does that interest necessarily outweigh other interests specifically legitimate privacy concerns? The answer must be no.

On this analysis, the fifth element of the requirement for a disclosure order under Rule 238 or the equitable remedy for disclosure is not met. Therefore an order for disclosure should not be given in these circumstances. If such an order is not given, then there is no exemption from the rights of the internet

165 See also PIPEDA, supra note 81, ss. 7(3)(c.2), (d). 
customers under PIPEDA and the ISPs must not disclose the identities of these customers to anyone other than the individual customers, upon request. What would the implications of such a finding be?

If the reasoning suggested herein is adopted and the identities of the ISP customers are not ordered disclosed in civil proceedings for copyright infringement, will the plaintiffs necessarily be completely without remedy? First of all, if the identities of the alleged infringers come to light other than through the channels of the ISPs, then the plaintiffs are free to continue their lawsuit. Secondly, the Copyright Act provides for criminal proceedings against those who infringe upon the rights of copyright holders. ${ }^{166}$ In the case of criminal proceedings, the public interest is much clearer than in disputes between private parties in civil proceedings. If rights holders invoke the criminal process, it would seem that there would be a much greater argument that the privacy rights of those against whom a sufficient case for disclosure can be made should be suspended in favour of the Queen's justice.

Is this result inconsistent with the general regime of intellectual property? No. Even within the copyright regime itself, the economic interests in copyright must be balanced both with moral rights interests and with users' rights. The economic interests in copyright such as those held by the plaintiffs in $B M G$ v. John Doe are not the only intellectual property rights related to the musical works and recordings involved in that case, and therefore it is too simplistic to conclude that the economic rights holders should necessarily be given priority ${ }^{167}$ as opposed to other rights holders - whether other rights holders within the copyright regime (authors or users) or those whose interests lie under personal data protection legislation or the legal protection of privacy. Thus, given that there is a public interest in supporting the copyright holder's pursuit of economic interests under the Copyright Act that must be balanced even within the copyright regime against the legitimate interests of moral rights holders and users, is the economic interest of rights holders in pursuing infringers through civil remedy of the infringement lawsuit so compelling as to outweigh privacy interests affected by that pursuit?

Is this result consistent with what little explicit guidance there is in legislation about the relationships between intellectual property rights and personal data protection legislation? Yes - while the evidence is sparse and indirect. ${ }^{168}$ It may be noted that s. 32.1(1) of the Copyright Act provides:

166 Copyright Act, supra note 6, s. 42-45(2).

167 As Sexton does in BMG FCA, supra note 2 at para. 42.

168 See Margaret Ann Wilkinson, 'The Copyright Regime and Data Protection Legislation' in Ysolde Gendreau, ed., Copyright Administrative Institutions (Cowansville, Que: Yvon Blais, 2002) 77. 
It is not an infringement of copyright for any person

(a) to disclose, pursuant to the Access to Information Act, a record within the meaning of that Act, or to disclose, pursuant to any like Act of the legislature of a province, like material;

(b) to disclose, pursuant to the Privacy Act, personal information within the meaning of that Act, or disclose, pursuant to any like Act of the legislature of a province, like information...

Nor is prioritizing personal data protection over disclosure for purposes of copyright litigation inconsistent with the positions of personal data protection and privacy under the Charter of Rights and Freedoms as compared to the position of intellectual property in terms of the Charter. As discussed earlier, informational privacy is not directly addressed in the Charter, although there are privacy-related provisions specifically set out in the Charter and jurisprudence around Charter protection for privacy has developed. The Supreme Court stated in Lavigne v. Canada that '...the Privacy Act has been characterized by this Court as "quasi-constitutional" because of the role privacy plays in the preservation of a free and democratic society'. ${ }^{169}$ In the more recent Heinz case, Justice Deschamps, writing for herself and Justices Binnie, Fish, and Abella, in the majority, held that privacy trumps access to government-held information, and that privacy rights are quasi-constitutional. ${ }^{170} \mathrm{On}$ the other hand, in the intellectual property context, lower courts had suggested that intellectual property was not subject to Charter scrutiny. ${ }^{171}$ However, in writing for the majority of the Supreme Court in Harvard College v. Canada, ${ }^{172}$ Justice Bastarache considered the implications of the Canadian Charter of Rights and Freedoms on the issues before the court involving the patentability of the 'Harvard Mouse'. ${ }^{173}$ Although he found the Charter was not helpful in deciding the issue before the Court, he was certainly prepared to apply the Charter in the context of intellectual property in an appropriate case. ${ }^{174}$ And it may also be useful to

169 Lavigne v. Canada (Office of the Commissioner of Official Languages), [2002] 2 S.C.R. 773 at 790. (It must be noted that the Privacy Act referred to is actually a federal personal data protection statute and not a privacy statute, as discussed above.)

170 Heinz, supra note 143 at para. 28.

171 Compagnie Générale des Établissements Michelin-Michelin \& Cie v. National Automobile, Aerospace, Transportation and General Workers Union of Canada (CAW-Canada), [1997] 2 F.C. 306 at para. 102, [1996] F.C.J. 1685 (F.C.T.D). 172 Harvard College v. Canada (Commissioner of Patents), [2002] 4 S.C.R. 45, 2002 SCC 76 [Harvard Mouse].

173 Ibid. at paras. $177-182$.

174 This scrutiny would be available for intellectual property devices legislated by Parliament - as is patent, the subject matter at hand in the Harvard Mouse case. This would also apply to copyright, trademark, or industrial design and so on. There would not be the possibility of Charter scrutiny over breach of confidential information at this time because this is a purely common law action and the Charter does not reach private parties. 
recall that the Supreme Court pointed out in the Heinz case that intellectual property rights can be altered by contract. ${ }^{175}$

Therefore, on balance, it appears that the economic interest of rightsholders in pursuing infringers through the civil remedy of the infringement lawsuit is not so compelling as to outweigh privacy interests affected by that pursuit. The decision of the Court of Appeal in BMG v. John Doe, while correct in the result, has left open the door to future litigation. The principles enunciated by Justice Sexton to guide that future litigation are not appropriate in the current Canadian context. His concerns with the relationships between intellectual property and property rights and between privacy and intellectual property rights are misplaced. The critical factor determining such future cases is the extension of personal data protection into the private sector in Canada. Parliament, in creating this environment, has articulated a very narrow scope for disclosure in terms of personal information and enhanced the confidentiality of relationships between individuals and commercial organizations in Canada. Since privacy is one thrust of personal data protection legislation, and there is no element of public access connected to the enactment of this legislation in the private sector, legitimate privacy concerns about disclosure have been dramatically recognized by the enactment of personal data protection legislation in the private sector in Canada. Whatever the state of the law of privacy across the various jurisdictions in Canada, the evidence of the enactment of PIPEDA is that 'public concerns for the protection of intellectual property rights' - other than intellectual property rights that lie at the heart of criminal proceedings - have given way to the public interest in personal data protection. And, while distinct from privacy, personal data protection is intimately related to privacy and certainly limits disclosure of personal information to third parties, rather than encouraging it. Thus, as intimated in the Tariff 22 decision, and consistent with Canada's international obligations, individuals confiding personal information to commercial organizations in Canada should be entitled to have those private confidences of personal information respected by the courts, whatever the civil litigation interests of third parties might be.

175 Heinz, supra note 143 at para. 20. 